\title{
Diagnosis of some blood parasites in cattle and sheep in Mosul, Iraq
}

\author{
M.H. Hasan
}

Department of Microbiology, College of Veterinary Medicine, University of Mosul, Mosul, Iraq

\begin{abstract}
Sixty blood smears from cattle and sixty blood smears from sheep were collected from various regions in Mosul city during October 2010 till October 2011. These were examined for parasites (Eperythrozoon, Haemobartonella, and Trypanosoma) and some clinical signs were observed on the affected animals. The percentage of infections in cattle were $28.33 \%, 10 \%$ and $3.33 \%$ for Eperythrozoon wenyoni, Haemobartonella bovis and Trypanosoma congolense respectively. Mixed infection with E. wenyori and $H$. bovis was $18.33 \%$. Percentage of infection with E. ovis was $40 \%$ with the mean parasitaemia of $2.29 \%$ in sheep. This study is the first report in Mosul city.
\end{abstract}

Keywords: Blood parasites; Eperythrozoon; Haemobartonella; Trypanosoma.

Available online at http://www.vetmedmosul.org/ijvs

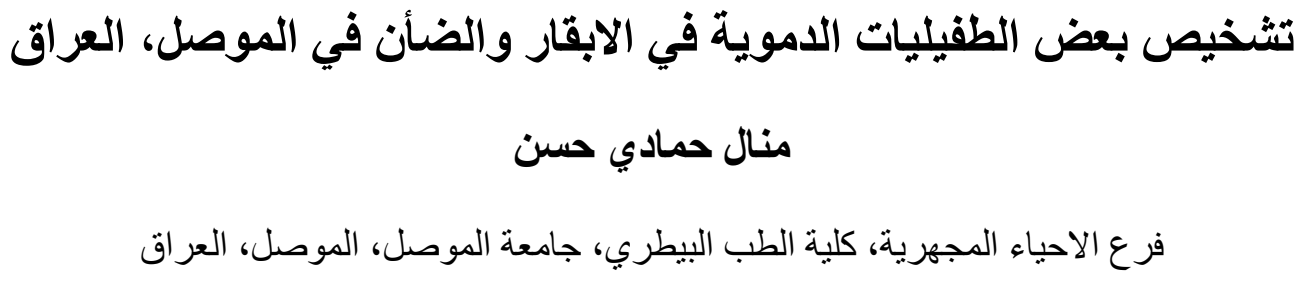

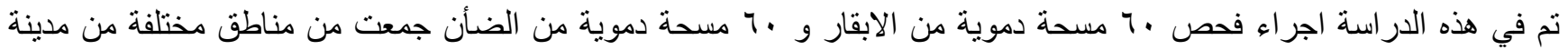

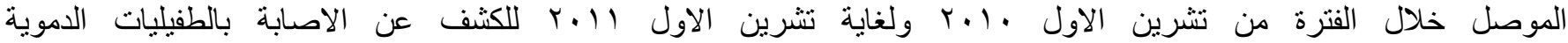
(Eperythrozoon, Haemobartonella, Trypanosoma)

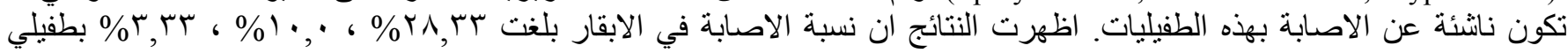

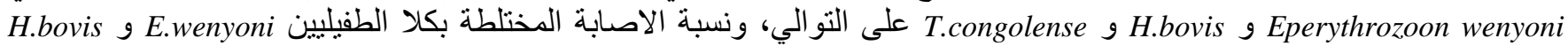

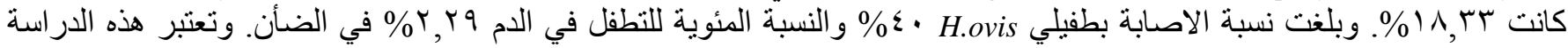
الاولى في الموصل للطفيليات المدروسة.

\section{Introduction}

Among the blood parasites in mammals are Eperythrozoon, Haemobartonella and Trypanosoma species. Which are extracellular of RBCs. Their effects on the susceptible hosts vary from mild effect to death (1-3). Haemobartonella and Eperythrozoon species are currently classified as Rikettsiae (order: Rickettsiales) because of their small size and staining properties; their uncultivated status; their transmission by arthropod vecrots and their haemotrophic character $(4,5)$. Haemobartonella and Eperythrozoon differ from Anaplasma in that they are wall less attach to the surface of red cells and do not invade erthtocytes (6). Haemobartonella and Eperythrozoon species in different animals have been shown to be transmitted by various blood - feeding arthropods, including tick, lice, fleas, flies and mosquitoes $(1,2)$.

Recently, Eperythrozoon and Haemobartonella have been reported in cattle, sheep, goat, pigs, dogs and cats as well as humans in several parts of the world $(1,2,7,8)$.

The difference between Haemobartonella and Eperythrozoon that Haemobartonella does not occur free in the plasma. In electron micrographs Haemobartonella appears more closely associated with the erythrocyte. Eperythrozoon adheres to the surface of erythrocytes and may occur as free $(7,9)$. 
Many infections caused by Eperythrozoon and Haemobartonella are clinically inapparent, but severe clinical signs, particularly in stressed animals usually includes haemolytic anaemia, icterus, poor weight gain and morbidity in lambs $(2,6,10,11)$.

Trypanosoma congolense is the smallest of the African Trypanosomes of about 9-18 $\mu$ in length (2). It is considered as the most economically important animal trypanosomosis in Africa (12). The effect of Trypanosoma species such as T.congolense and T.vivax on the ruminants range from anaemia, immunosuppression, retarded growth, low milk production and weight loss (13-16). As well as $T$. congolense causes scruffy hair coats appear "potbellied" and have fever, intermittent diarrhea and exercise intolerance (17).

The aim of this study is to investigate the presence of blood parasites which are extra cellular of red blood cells in cattle and sheep in Mosul city.

\section{Material and methods}

Random blood samples were collected from jugular veins of local undescriptive breed of 60 cattle and 60 sheep of both sexes and in different ages from animals which brought by owners to the Teaching Veterinary Hospital, College of Veterinary Medicine, University of Mosul, from various regions in Mosul city (Al-rashedia, Al-nahrawaan, Al-shalalaat, Al-kahera, Al-arbagia, felfeel, Goggeli), during the period from October 2010 till October 2011. All animals were examined clinically and sings were recorded before blood samples were taken.

Blood smears were made fixed and Giemsa stained as described by (18) then examined microscopically to identify blood parasites, and parasitaemia were estimated $(7,9)$ and photographed by digital camera.

\section{Results}

In this study, some clinical sings were observed on animals during sampling. The clinical findings included pale mucous membrane, jaundice and emaciation. The examination of blood smears of cattle revealed the percentages of infection with E.wenyoni, H.bovis, T.congolense in the affected animals. Highest percentage infection was $28.33 \%$ with E.wenyoni in cattle with lowest $3.33 \%$ with T.congolense.

Mixed infection with Eperythrozoon and Haemobartonella was $18.33 \%$ in cattle. see (Table 1, Fig 1).

The percentage of parasitaemia ranged between 0.36$3.5 \%$, with mean of $1.81 \%$ in cattle while that in sheep was $0.4-4.5 \%$ with a mean of $2.29 \%$ (Table 2 ).
The examination of sixty blood smears of sheep revealed E.ovis was detected in sheep smears with percentage $40 \%$, in 24 of affected animals (Table 1).

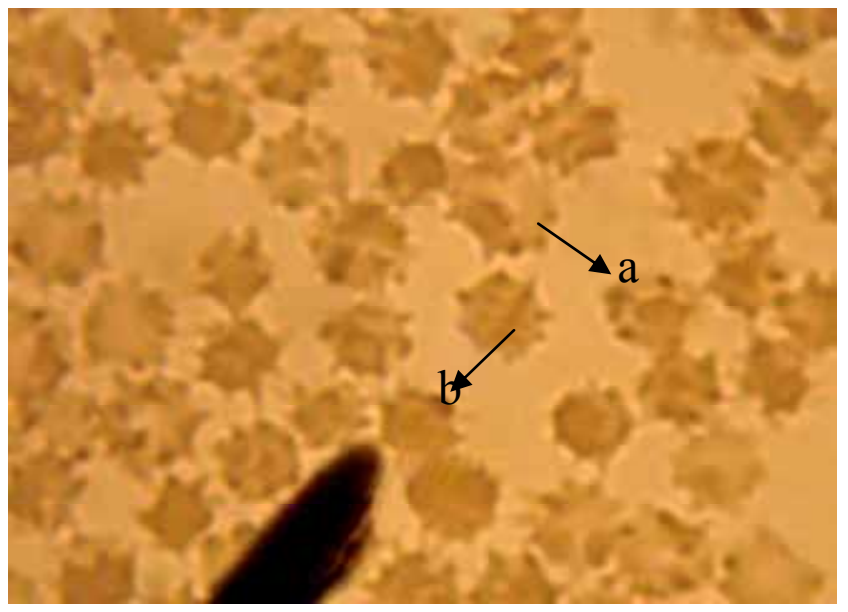

Figure 1: Mixed infection with a: E. wenyoni and b: H.bovis in blood smear of cattle (100x).

Table 1: The percentages of infection in cattle and sheep with blood parasites (extracellular).

\begin{tabular}{lcc}
\hline The parasite & $\begin{array}{c}\text { Number of } \\
\text { affected animals } \\
\text { (cattle) }\end{array}$ & $\begin{array}{c}\text { The percentage } \\
\text { of infection\% }\end{array}$ \\
\hline $\begin{array}{l}\text { E.wenyoni } \\
\text { H.bovis }\end{array}$ & 17 & 28.33 \\
$\begin{array}{l}\text { Eperythrozoon and } \\
\text { Haemobartonella }\end{array}$ & 11 & 10.0 \\
T.congolense & 2 & 18.33 \\
E.ovis & 24 (sheep) & 3.33 \\
\hline
\end{tabular}

Table 2: The percentages of parasitaemia from E.wenyoni and E.ovis in 30 blood smears.

\begin{tabular}{lccc}
\hline \multirow{2}{*}{ The parasite } & \multicolumn{3}{c}{$\begin{array}{c}\text { The percentage of } \\
\text { parasitaemia\% }\end{array}$} \\
\cline { 2 - 4 } & Range & \multicolumn{2}{c}{ Mean S.E. } \\
\hline E.wenyoni in cattle & $0.36-3.5$ & 1.81 & \pm 0.14 \\
E. ovis in sheep & $0.46-4.52$ & 2.29 & \pm 0.09 \\
\hline
\end{tabular}

The parasite of the genus Eperythrozoon appeared in blood smear as cocci, spheres clustered on the surface of the red cells (extracellular) and are found in the intercellular space. In heavy infections, chains of the parasites surrounding the margin of the red cell, measuring about $0.8-1 \mu$ (Fig 2). 


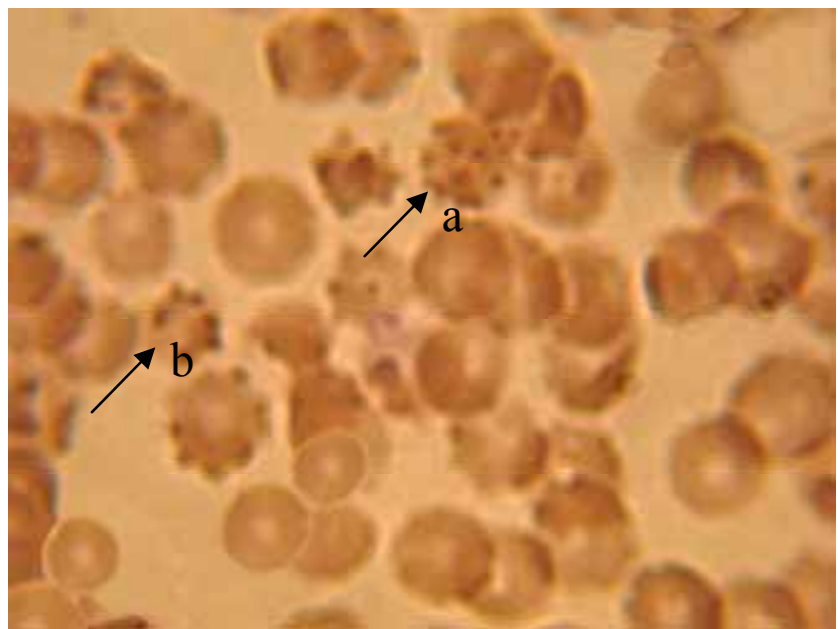

Figure 2: E.wenyoni in blood smear of cattle (100x), (a) cocci form, (b) chains of parasites surrounding the margin of red cell.

The genus Haemobartonella appeared in blood smears as rod shaped forms are usually located around the periphery of the red cell, and are not free in the plasma (Fig. 3).

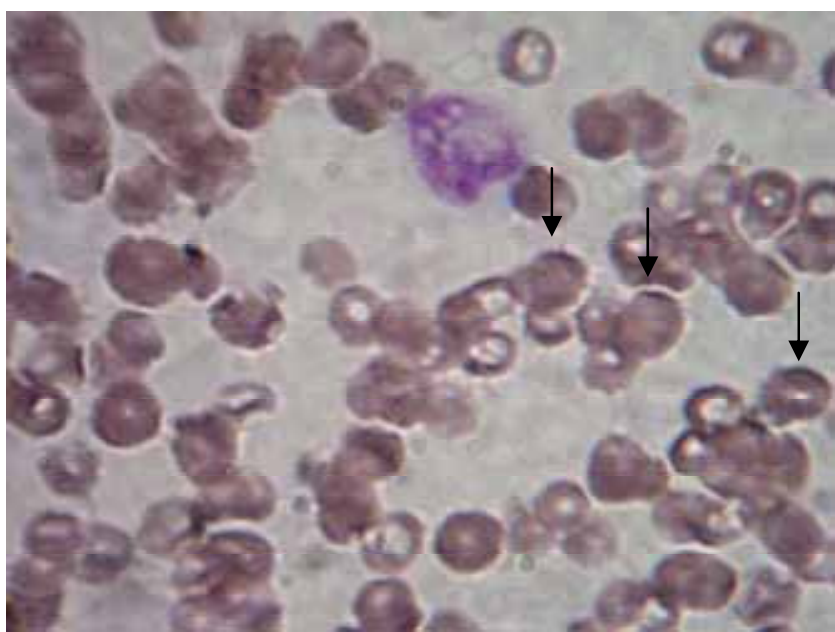

Figure 3: H.ovis in blood smears of sheep as rod - shaped form is located around the periphery of the red cells (100x).

The Eperythrozoon were seen free in the plasma in countarary to Haemobartonella sp. which were not free in the plasma. Morphological alteration of the erythrocytes in the blood smears of the affected animals were observed (see Fig. 1 and 2).

Trypanosoma congolense appeared in blood smears of cattle is monomorphic in form ranging from $8.0-10 \mu$, the kinetoplast is marginal and the posterior end is blunt. There is no free flagellum (Fig 4).
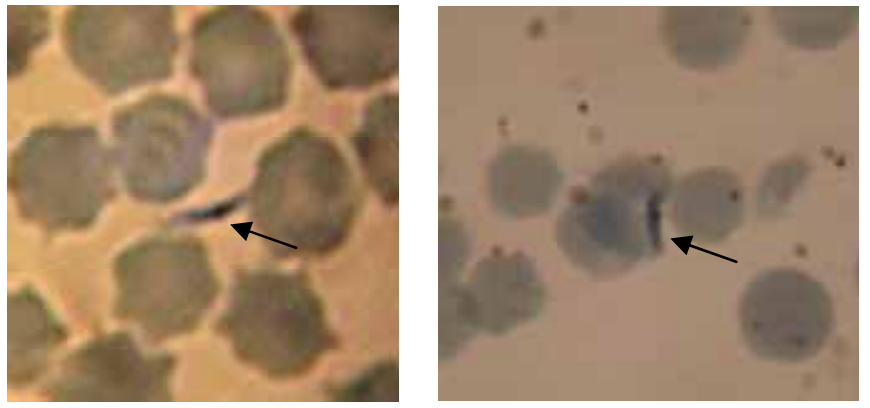

Figure 4 : T.congolense in blood smear of cattle (100x).

\section{Discussion}

In this study the diagnosis of E.wenyoni, H.bovis and Trypanosoma congolense in blood smear of cattle and E.ovis in blood smear of sheep, was made in Mosul city. It is noteworthy that there was no previous reports for the occurrence of these blood parasites in native breeds of animals in northern part of Iraq. Therefore this is the first report on the parasites in Mosul, Iraq. Previous study by (9) reported E. wenyoni in Turkey in cattle. And E.wenyoni was also reported in cattle of Saudi Arabia (19-21).

The results of this study showed that the clinical sings observed in infected animals were in agreement with the results of other studies carried out in other countries $(9,10,19,22)$. These parasites cause anaemia, fever, anorexia, weight loss and decreased milk production and infertility (23-25). Most of the tested animals were subclinical infected (25). In this study the percentages of Eperythrozoon in cattle and sheep were $28.33 \%, 40.0 \%$ respectively. Whereas Al-khalifa et al. (19) recorded 1-4\% of infection with E.wenyoni in cattle and 2-9\% of infection with E.ovis in Saudi Arabia. The mixed infection with Eperythtozoon and Haemobartonella were diagnosed in blood smears of cattle, which were also described by $(9,24)$

In Australia Eperythrozoon infection was reported in $10 \%$ of weaner and $51 \%$ of adult sheep (26). Eperythrozoon and Haemobartonella observed in this study could be due to the favourable environmental conditions for the survival and proliferation of the arthropods vectors such as fleas, mosquitos, and tick. $(6,27)$ referred that the Eperythrozoon and Haemobortonella are transmitted mechanically by arthropods such as Fleas and Mosquitos transmission the Eperythrozoon in sheep and goats, Ticks (Rhipicephalus) are vectors of Eperythrozoon for cattle, also transmission may occur via surgical procedures through blood contaimination of instruments (needle contamination during vaccination). 
In present study, the result revealed that the E.wenyoni and E.ovis appeared as minute bluish coloured cocci, rings, spheres clustered on the surface of RBCs and found free in plasma. Haemobartonella bovis appeared chains of rods are usually around the periphery of RBCs. Many authers mede similer reports on these parasites $(7,28,29)$. The percentages of parasitaemia of E.bovis and E.ovis were 1.81\%, 2.29\% respectively. Cem Ecmel SAKi 2009 (9) mentioned that the parasites numbers of E.wenyoni ranging from 1-50, in highlydense parasitaemia, While (29) attributed to the anaemia. Parasitaemia develops during the pyretic stage at which time parasites can be found in great numbers on the red cells and in the plasma (28). In case of Eperythrozoon infection, the mechanism of disease appears similar to that occurs of other blood parasites, where in inmmunemediated hemolysis within macrophages follows attachment of the organisms to erythrocytes (17)

In this study, during the examination of 60 blood smears of cattle, Trypanosoma was diagnosed in 2 animals with percentage of $3.33 \%$. These parasite appear in blood smear as a small size about $8-10 \mu$ in length, with blunt posterior end, and no free flagellum therefore determined the species as T.congolense dependened on $(2,7)$.

Probably introduced the affected animals with T.congolense from different regions into the Mosul city and because the transmission of T.congolense by Glossina and as well as they can also be transmitted mechanically by other biting flies such as Tabanas and Stomoxys.

Authors (30) mentioned that after trypanosomes have been introduce into a herd transmission is possible even in the absence of Glossina-Biting flies such as Tabanidas, Stomoxyinae and Hipoboscidae are capable of mechanically transmitting trypanosomes. Mechanical transmission can through the needle during inoculations and in carnivores infected carcasses.

Samdi etal 2011 (31) recorded that 50\% in cattle in kaduna central abattoir, North central Nigeria were infected with $T$. congolense. whereas ohaeri (32) recorded the percentage of infectin in cattle with T.congolense of $42 \%$ in Nigeria. However these parasites are more predominant in small ruminants. The variation in results in different studies may be because the variation in strain of parasite, the vector, breed and management of animals as well as the season of the year during the study. Some of the factors that affect the prevalence of trypanosomiasis in Nigeria include: animal breed, type of management season, of the year and the type of vegetation (33).

\section{Acknowledgment}

This study was supported by the College of Veterinary Medicine, University of Mosul.

\section{References}

1. Urquhart Gm, Armour J, Duncan J L, Dunn AM, Jennings Fw. Veterinary parasitology $2^{\text {nd }}$ ed. Black well science Ltd., Oxford; 2003: p 252

2. Soulsby FJL Helminths, Arthropods and Protozoa of domesticated animals $7^{\text {th }}$ edition. London. Philadelphia Toronto; 1982:p 526, 754756

3. Robson S and Kemp B. Eperythrozoonsis in sheep. [Internet] state of new south wales, 2007.: http://www.dpi.nsw-gov.au/primefacts

4. Kreier JP and Ristic M. Genus IIT Heamobartonella; Genus IV Eperythrozoon In Bergey's manual of systematic Bacteriology. 1984; 1: 724-729 Edited by Krieg NR Holt Baltimore JG m MD: Williams \& Wikins

5. Quinlan JF. Scientific letter. Suspected Eperythrozoonsis in diary cows. Irish Vet J. 1985; 39:27.

6. Neimark H, Johansson KE, Rikihisa Y, Tully JG. Proposal to transfer to some members of the genera Heamobartonella and Eperythrozoon to the genus Mycoplasma with descriptions of "Candidatus Mycoplasma haemofelis" "Candidatus Mycoplasma haemomuris" "Candidatus Mycoplasma haemosuis and "Candidatus Mycoplasma wenyonii". IJSEM 2001; 51:891-899

7. Adam KMG, paul J, Zaman V. Medical and Veterinary Protozoology Churchill. Livingstone Edinburg and London; 1971: p76-77,136-137

8. Zhibiao Y, Congli Y, Fei Y, Xinguo H. Haemotrophic mycoplasma: review of aetiology and prevalence. Med Microbiol. 2007; 18: Issue 1 P1-3

9. Cem Ecmel SAKi. Clinical Eperythrozoon wenyoni (Adler and Ellenbogan, 1934) and Heamobartonella bovis (Donatin) and Lestoquard, 1934) infection in a cattle F. Ü sağ.Bil Vet Dreg. 2009; 23(2) : 117118

10. Love SCJ Hutchinson GW. Pathology and diagnosis of internal parasites in ruminants In Gross Pathology of Ruminants, Proceedings 350,Post Graduate Foundation in Veterinary Science, University of Sydney, Sydney;2003:309-338

11. Burroughs GW. The significance of Eperythrozoon ovis in ill-thrift in sheep in the eastern cape coastal areas of South Africa JSA fr Vet Assoc.1988; 59(4) : 195-9

12. Gillingwater K, Mamabolo MV Majiwa PA. Prevalence of mixed Trypanosoma congolense infections in livestock and tsetse in kwazulu-Natal, South Africa JSA fr Vet Assoc. $2010 ; 81(4)$ : 219-23.

13. Anosa VO. Haematological biochemical changes in human and animal trypanosomiasis. Part1 Revue Elev Med Vet Paystrop. 1988; 41(1): $65-78$

14. Edeghere H, Elhassan E, Abenga J, Osue HO,Lawani FAG Falope O. Effects on infection with Trypanosoma brucei on different trimesters of pregnancy in ewes Vet parasitol. 1992; 43: 203-209

15. Elhassan E, Ikede BO Adeyemo O. Trypanosomiasis and production : 1-Effect of Trypanosoma vivax infection on the oesrrus cycle and fertility in the ewe Trop Anim Hlth Prod. 1994; 26: 213-218

16. Losos GJ Ikede BO. Review of pathology of disease in domestic and loboratory animals caused by $T$. vivax,T.brucei, $T$. rhodesiense and $T$. gambiense. Vet pathol suppl. 1972; $9: 1-17$

17. Mc Gavin MD, Carlton WW Zachary J F. Special veterinary pathology $3^{\text {th }}$ ed Mosby, Inc. USA; 2001, 334-335.

18. Hendrix CM. Diagnostic Veterinary Parasitology $2^{\text {nd }}$ Edition. Mosby Inc, United State of America 1998: 266-267

19. Al-Khalifa MS, Hussein HS, Diab FM, Khalil GM. Blood parasites of livestock in certain regions in Saudi Arabia Saudi J Biol Sci. 2009; 16:63-67

20. Hussein M HS Al-Asgah NA, Al-Khalifa MS, Diab FM. The blood parasites of indigenous livestock in Saudi Arabia. Arab Gulf J Sci Res. $1991 ; 9: 143-160$

21. Al-khalifa MS, Khalil GM, Hussein HS, Diab FM. Apreliminary study on the effect of a concurrent infection with calves.Saudi J Biol Sci. $2008 ; 15: 73-79$ 
Iraqi Journal of Veterinary Sciences, Vol. 26, Supplement II, 2012 (57-61)

Proceedings of the $6^{\text {th }}$ Scientific Conference, College of Veterinary Medicine, University of Mosul

22. Adejinmi JO, Sdiq NA, Fashanu SO, Lasisi OT Ekundayo S. Studies on the blood parasites of sheep in Ibadan, Nigeria. Afr J Bio Res. 2004; 7:41-43

23. Smith JA, Thrall MA, Smith JL, Salman MD, Ching SV and Collins JK. Eperythrozoon wenyonii infection in dairy cattle. J Am Vet Med Assoc. 1990; 196: 1244-1250

24. Messick JB. Hemotrophic mycoplasmas (hemoplasmas): a reviews and new insights into pathogenic potential. Vet Clin Pathol. 2004; 33:2-13

25. Montes, AJ wolfe DF, welles EG, Tyler JW Tepe E.Infertility associated with Eperythrozoon wenyonii infection in abull. J Am Vet Med Assoc. 1994 ; 204:261-263

26. Nicholls TJ Veale The prevalence of Eperythrozoon ovis in weaner and adult sheep North Eastern Victoria Aust Vet J. 1986 ; 63(4): 118120

27. Kahn CM Line S. The Merck Veterinary Manual tenth ed., white house station, NJ USA.2010. on line at www.merckbooks.com
28. Jain NC, keeton KS. Eperythrozoon wenyoni : A scaning Electron Microscope study J Parasitol. 1973; 59(5):867-873

29. Coles EH. Vererinary Clinical Pathology $4^{\text {th }}$ ed. Philadelphia: W.B. Saunders Co; 1986:p 382-383.

30. Rodistitis OM Gay CC Hinchcliff KW, Constabl PD. Veterinary Medicine A text book of the diseases of cattle horses, sheep,pigs and goats. $10^{\text {th }}$ ed. Philadephia:W.B. Saunders company ; $2007:$ p 15321533

31. Samdi SM, Fajinmi AO, Kalejaye JO, Wayo B, Haruna MK, Yarnap JE, Mshelia WP, Usman AO, Harma SM, Jijitar A, Oqunwole R, Ovbagbedia RP, Bizi R. Prevalence of trypanosomosis in cattle at slaughter in kaduna central Abattoir Asian J Anim Sci 2011; (5) : 162165

32. Ohaeri CC. prevalence of trypanosomiasis in Ruminants in parts of Abia state, Nigeria J Anim Vet Adv 2010; 9(18) : 2422-2426

33. Maclaennnan KJR. Tsetse-transmitted trypanosomiasis in relation to rural economy in Africa part 1 Tsetse infestation FAo Amin. Prod. Hlth. 1983 ; 37 : 48-63. 